Marquette University

e-Publications@Marquette

Economics Faculty Research and Publications

Economics, Department of

$11-1-2015$

\title{
Terms of Trade Shocks and Private Savings in the Developing Countries
}

Abdur Chowdhury

Marquette University, abdur.chowdhury@marquette.edu

Accepted version. Journal of Comparative Economics, Vol. 43, No. 4 (November 2015): 1122-1134.

DOI. (C) 2015 Elsevier B.V. Used with permission. 
Marquette University

\title{
e-Publications@Marquette
}

\section{Economics Faculty Research and Publications/Department of Economics}

This paper is NOT THE PUBLISHED VERSION; but the author's final, peer-reviewed manuscript.

The published version may be accessed by following the link in the citation below.

Journal of Comparative Economics, Vol. 43, No. 4 (2015): 1122-1134. DOI. This article is (C) Elsevier and permission has been granted for this version to appear in $\underline{\mathrm{e}}-$

Publications@Marquette. Elsevier does not grant permission for this article to be further copied/distributed or hosted elsewhere without the express permission from Elsevier.

\section{Terms of trade shocks and private savings in the developing countries}

\section{Abdur R. Chowdhury}

Department of Economics, Marquette University, Milwaukee, WI

\begin{abstract}
Economic agents in the developing countries are subject to tight credit constraints, which are more pronounced during bad state of nature. Thus, adverse shocks to commodity prices in the world market can force them to reduce savings by a larger amount than they would otherwise have. Empirical analysis using a dynamic GMM model and data from 45 developing countries confirm that most of the determinants of savings identified in the literature also apply to the developing countries. The transitory component in the terms of trade have a larger positive impact than the permanent component. This reflects the lack of access to foreign borrowing. Although the impact of terms of trade shocks is found to be asymmetric, the magnitude of the impact appears to be relatively small. Results show some differences in the response of savings in the three regions considered here. The results are, however, robust for alternative estimators and determinants.
\end{abstract}




\section{Keywords}

Private savings, Terms of trade, GMM estimation, Developing countries, Shocks

\section{Introduction}

There has been a voluminous literature on the potential importance of terms of trade shocks in explaining macroeconomic performance. ${ }^{1} \mathrm{~A}$ question regularly raised in these studies is: how should economic agents respond to greater fluctuations in tradable commodity prices, and the resulting volatility in current account balances and real income? This question is particularly relevant as commodity exporting countries across the world have benefitted largely from the commodity price boom of the last decade. One answer, provided by the theory of precautionary savings, suggests that in response to an increase in the volatility of income arising, say, out of an increase in the probability of being unemployed, economic agents would increase savings in order to hedge against the greater problem of a large negative income shock in the future. The international economics literature beginning with studies by Obstfeld (1982), Sachs (1981) and Svensson and Razin (1983) have devoted particular attention to the response of private savings to terms of trade shocks in the context of macroeconomic models where spending decisions are based on intertemporal optimization by forwardlooking agents. An important result emerging from this work is that the nature of the impact of these shocks on private savings depend on whether the shocks are permanent or transitory, and expected or unexpected.

However, most of the empirical studies in this area have concentrated on the developed economies. Very few studies have considered the developing economies. This paper attempts to fill this gap in the literature. Why is this an important issue for the developing economies? Terms of trade disturbances have been an important source of macroeconomic uncertainty in a number of these countries (Adler and Magud, 2013; Osterholm and Zettelmeyer, 2008). ${ }^{2}$ Many of them remain heavily dependent on primary commodities increasing their vulnerability to external shocks, and complicating macroeconomic management, particularly on the fiscal side (Adler and Magud, 2013; Cespedes and Velasco, 2011; United Nations, 2002, pp. 139-46). Recent events associated with, on the one hand, the sharp decline in commodity prices, and, on the other, the continuous increase in the volatility of commodity prices have exacerbated the pressure on the current account of these countries.

For example, since 2008, the rebound in world oil price has helped to boost the OPEC and other oil producing economies, while many of the non-oil producing countries have faced substantial terms of trade losses as export prices of non-fuel commodities and other primary products remain generally depressed, particularly in real terms, while energy import prices have risen. ${ }^{3}$ Moreover, commodity price changes have also been asymmetric often with long troughs and sharp peaks, making it difficult to insulate the domestic economy from such shocks (Cashin et al., 2002; Spatafora and Warner, 1999). ${ }^{4}$

Given the absence of efficient domestic credit and capital markets and limited access to international financial markets, economic agents in the developing economies are subject to tight credit constraints which are more pronounced during bad state of nature. Consequently, adverse shocks to commodity prices in the world market can force them to reduce savings by a larger amount than they would otherwise have. Empirical studies on the impact of terms of trade shocks on private savings have excluded the developing economies on the ground that their performance is less amenable to explanation using standard economic variables (Agenor and Aizenman (2004) on Sub-saharan Africa and 
Aquino and Espino (2013) on Peru are exceptions). This is one of the first studies that we are aware of that tackles this issue for the developing countries with the realistic expectation of obtaining results comparable in quality and reliability to those available in the literature.

This paper studies the impact of terms of trade shocks on private savings in 45 developing countries over the 1990-2008 sample period. The paper uses the Generalized Method of Moments (GMM) dynamic panel regression framework that controls for bias arising out of the presence of simultaneity, use of lagged dependent variable and omission of country-specific effects (Edison et al., 2002). This, however, gives rise to a number of potential problems as discussed in the literature (see Campos and Kinoshita, 2002). We try to address these concerns by using several different estimators. First, we conduct estimations including country and time fixed effects to account for unobserved country characteristics and for common shocks and trends across countries. Our preferred choice of estimator to deal with the likely (weak) endogeneity in the relationship is the System GMM dynamic panel data estimator proposed by Arellano and Bover (1995) and Blundell and Bond (1998).

We compute robust two-step standard errors by following the methodology proposed by Windmeijer (2004). This approach addresses the issues of joint endogeneity of all explanatory variables in a dynamic formulation and of potential biases induced by country-specific effects (Dabla-Norris and Srivisal, 2013). Moreover, in order to address biases due to reverse causality, we run regressions lagging all regressors one period and we conduct dynamic system Generalized Method of Moments (GMM) estimations à la Arellano and Bover (1995), using lagged regressors as instruments. We also perform a battery of sensitivity tests to check the robustness vis-à-vis alternative estimators, determinants and country groupings, and we verify that our findings are indeed relatively robust.

The paper is organized as follows. Section 2 reviews the literature, while the methodology is discussed in the subsequent section. Empirical results and sensitivity test analyses are presented and discussed in Section 4. The paper ends with concluding remarks in the final section.

\section{Literature review}

What is the impact of movements in the external terms of trade on private savings? This question has been a source of a major debate in international economics for the last few decades. ${ }^{5}$ The traditional explanation, known as the Harberger-Laursen-Metzler (HLM) effect (Harberger, 1950; Laursen and Metzler, 1950), states that an improvement in the terms of trade increases a country's real income level (that is, raises the purchasing power of its exports in the world market) consequently increasing savings. A deterioration in the terms of trade can be shown to lower private savings. Obstfeld (1982) and later Kent and Cashin (2003) extended this idea and showed that the duration or persistence of terms of trade shocks are important when determining the effect on an economy. A longer or more persistent shock may result in lower investment and potentially higher saving in anticipation of lower future output.

In later years, the literature moved in two different directions. The Dutch Disease literature built on the tradable-non-tradable dichotomy and concentrated on the sectoral impact of terms of trade shocks (see Corden, 1984, for a detailed survey). On the other hand, the intertemporal choice literature, following studies by Obstfeld (1982), Sachs (1981) and Svensson and Razin (1983), questioned the theoretical basis of the HLM effect and argued that in two-good models (imports and exports) household saving decisions should be derived from solutions to a dynamic optimization problem of selecting consumption 
and savings at different points in time. These studies concluded that the relationship between terms of trade and savings is sensitive to the duration of the terms of trade shocks. For instance, if improvements in the terms of trade are expected to be permanent, economic agents will revise upward their estimate of national income in current as well as future periods. In sharp contrast to the HLM effect, the higher level of income would lead to higher level of consumption with no effect on savings. On the other hand, if improvements are expected to be temporary, economic agents will smooth this windfall gain over future periods by raising savings. Hence the HLM effect holds in the presence of only transitory terms of trade shocks.

Later studies (Dornbusch, 1983; Edwards, 1989) questioned the view that transitory shocks to the terms of trade have unambiguous effect on private savings. Using a three good (imports, exports, nontradables) model, these studies showed that an adverse terms of trade shock can affect private savings in three different ways (Chowdhury, 2004). First, it will lower the current national income relative to future national income (consumption-smoothing or HLM effect). Second, it will increase the price of current imports relative to future imports leading consumers to postpone their purchases, that is, save more (the consumption-tilting effect). Third, it will increase the import prices relative to the price of the non-tradables, thereby leading to an appreciation of the real exchange rate. This, in turn, will increase the consumption rate of interest and provide an incentive to postpone current consumption and increase savings (the real exchange rate effect). As pointed out by Cashin and McDermott (2002), in response to an adverse transitory terms of trade shock, private savings will increase (decrease) if the consumption smoothing effect dominates (is weaker than) the saving-enhancing effects of the consumption-tilting and real exchange rate effects. ${ }^{6}$

Agenor and Aizenman (2004) have suggested that terms of trade shocks can also lead to an asymmetric response in savings. Slumps and booms in commodity prices may trigger different response to welfare changes. Households may not be able to smooth consumption when faced with adverse shocks to the terms of trade due to the presence of, say, increased borrowing constraints in the international financial markets. Consequently, in order to maintain a smooth consumption path, economic agents may be forced to dissave by a larger amount than they would otherwise have. To the extent that domestic agents internalize the possibility of facing restrictive borrowing constraints during hard times, they may also consume less and save more in good times. Given that many households in the developing economies are faced with credit constraints, the possibility of an asymmetric effect of terms of trade on savings cannot be ruled out.

This paper extends Agenor and Aizenman (2004) in a number of ways. First, the paper considers an array of developing countries from different regions in Africa, Asia and Latin America. This would help to see if the results are sensitive to region specific economic conditions. Second, the issues of joint endogeneity of all explanatory variables in a dynamic formulation and of potential biases induced by country-specific effects are directly addressed. This provides more consistent estimators. Third, a battery of sensitivity analysis is conducted to check the robustness of the results. These include the use of alternative determinants, estimation dropping one country at a time in order to identify an outlier country, country groupings, etc. Finally, an extreme bound analysis is performed to test the reliability and robustness of the relationship between terms of trade shocks and the savings rate. 


\section{Methodology}

Three issues need to be considered in selecting an estimation procedure. First, we want to allow for inertia in savings ratio that may arise from lagged effects of the explanatory variables on savings. ${ }^{7}$ Second, some regressors included in the equation such as real income growth and public savings may be jointly endogenous, that is, correlated with the error term. Third, unobserved time- and country-specific factors may be correlated with the explanatory variables producing biased and inconsistent estimates.

We address these problems by implementing a one-step - dynamic System GMM estimation (Arellano and Bover, 1995; Blundell and Bond, 1998). We consider fiscal variables as a predetermined regressor in our model, and the conflict measure as an endogenous variables, given the possibility of both reverse causality and simultaneity bias. Our instrument for the lagged dependent variable is its own first lag, while we instrument all other endogenous variables with their own second lags in the differenced equation. The results we report correspond to a specification where, say, GDP is considered exogenous, but the effect of conflict on fiscal capacity is not changed if inflation is considered as an endogenous variable; however, in the latter case instrument proliferation impedes an appropriate evaluation of the join exogeneity of instruments. It should be noted, in any case, that the causality from fiscal capacity to GDP should materialize mainly in the long run, given that we control for country fixed effects, and thus focus on within country variability, declaring GDP as exogenous in the present setting is not implausible (Cardenas et al., 2011).

It is worth mentioning that the System GMM estimator requires that the first differenced instruments used for the variables in levels be uncorrelated with the unobserved country effects. We make this assumption in all our estimations. That is, we assume that the first differences of both our lagged values of fiscal capacity and contemporaneous values of conflict are uncorrelated with any country-specific characteristics. While the levels of conflict and fiscal capacity must be correlated with country fixed effects, it seems plausible to assume that changes in these dimensions do not reflect fixed characteristics of countries.

The estimates of the System GMM are, in principle, fully consistent. The diagnostics are satisfactory: the Arellano and Bond (1991) tests for first and second order serial correlation in the differenced equation suggest that, consistent with the underlying assumptions, the former is present but the latter is not; the Hansen statistics seem tolerable. Strikingly, conflict now emerges as both substantially larger and more significant.

For the GMM estimates, the table reports serial correlation tests, a Sargan test, and a Difference Sargan test. The serial correlation tests are used to examine the null hypothesis of no first-order serial correlation and no second-order serial correlation, respectively, in residuals in first-differences. Given the errors in level being serially uncorrelated, we would expect to find significant first-order serial correlation, but no significant second-order correlation in the first-differenced residuals. The Sargan test of over-identifying restrictions is used to examine the overall validity of the instruments by comparing the sample moment conditions with their population analog. The Difference Sargan test, proposed by Blundell and Bond (1998), is used to test the null hypothesis that the lagged differences of the explanatory variables are uncorrelated with the errors in the levels equations.

The savings equation includes a broad range of savings determinants. ${ }^{8}$ Thus 
(1)

$$
\begin{aligned}
\mathrm{PS}_{t}= & a_{0}+a_{1} \mathrm{PS}_{i, t-1}+a_{2} \mathrm{RPCY}_{i t}+a_{3} \mathrm{GRPCY}_{i t}+\frac{a_{4} \mathrm{M} 2}{\mathrm{GDP}_{i t}}+a_{5} \mathrm{INF}_{i t}+a_{6} \mathrm{PUBSAV}_{i t}+a_{7} \mathrm{DEP}_{i t}+a_{8} \mathrm{PTOT}_{i t} \\
& +a_{9} \mathrm{TTOT}_{i t}+a_{10} \mathrm{VTOT}_{i t}+a_{11} \mathrm{DUMMY}
\end{aligned}
$$

Specifically, in the basic equation, the per capita savings rate (PS) is modelled as a function of the oneperiod lagged per capita savings rate (PSt-1), real per capita income (RPCY), real per capita GDP growth (GRPCY), level of monetization (M2/GDP), inflation rate (INF), the ratio of public savings to gross national disposable income (PUBSAV) and dependency ratio (DEP). To analyze the impact of terms of trade, four variables (PTOT, TTOT, VTOT, DUMMY) are added to the basic equation. PTOT and TTOT are the permanent and transitory components of the terms of the trade, respectively, while VTOT measures its volatility. The dummy variable (DUMMY) captures the presence of any asymmetric effect of the terms of trade.

\subsection{Rationale for the explanatory variables}

The lagged private savings rate can be an important predictor of the current savings rate as it captures the habit formation effects and measures the rate of partial adjustment of the desired savings propensity to its actual value. ${ }^{9}$ Real per-capita income is a major determinant of savings in both the permanent income and the life-cycle hypotheses (Dayal-Gulati and Thimann, 1997; Kent, 1997; Lahiri, 1989). However, the impact of income on savings has been inconclusive in theoretical models. The simple permanent income theory predicts that higher economic growth reduces private savings. In contrast, the intertemporal optimising models, such as, the life-cycle model, suggest a positive relationship between national income and private savings. Most of the cross-country empirical studies find that permanent increase in income has a positive effect on private savings rate. ${ }^{10}$ The striking economic decline in a number of developing economies and the subsequent economic recovery are expected to affect significantly private savings, as these decline and recovery were associated with dramatic and heterogenous shocks to real income.

The GRPCY captures the business cycle effect and should have a positive impact on savings. The level of monetization is measured by the share of broad money in GDP. This is a realistic proxy for financial development and reform in the developing economies, as those that have made the most progress in reforming their financial systems in terms of rehabilitation and privatization of the banking system, establishing and enforcing prudential banking regulations, and establishing functioning capital market are also among those with the highest monetization ratios (UN, 2001). The sign of this variable is ambiguous. As far as it represents the development of the financial system in the country, it should have a positive effect on savings. Zeldes (1989) has, however, argued that the monetization variable should have a negative sign as it captures the borrowing constraints faced by the consumers and thereby reduces their ability to smooth consumption through borrowing.

The inflation (INF) variable, measured as the annual percentage change in the CPI, should have a negative impact on the savings rate as it reflects precautionary savings effect due to macroeconomic instability and income variability (Fischer, 1993).

Fiscal policy can potentially affect private savings through revenue policy (say, tax structure), expenditure policy (say, income distribution) or the extent of public savings. The rationale is to find out the extent to which the private sector in these countries internalises the government budget constraint 
and hence the extent to which a change in public savings leads to a change in private savings. Hence public savings is included here. The variable PUBSAV measures public savings as a ratio of GDP.

The dependency ratio DEP captures the life-cycle effect and is included to measure the impact of demographic variables on the savings rate. As aggregate data on private savings include both savings by the working population and dissaving by the retired, demographic changes with respect to the relative size of these two groups could also offset private savings. A number of countries in the sample have undergone dramatic demographic transition. Very low birth rates have led to a precipitous drop in the fraction of the population under the age of 15 . Combined with an increasingly mobile population, this has weakened an important source of support in old age children. The variable DEP is included in the model and is measured as the ratio of the difference between the total population and the employed labor force to the total population. ${ }^{11}$

Next, following Agenor and Aizenman (2004) and Cashin and McDermott (2002), a set of variables measuring the possible impact of terms of trade shocks are included in the model. The terms of trade is computed as the ratio of merchandise exports to the merchandise imports deflator from the IMF's International Financial Statistics with 1995 as the base year. ${ }^{12}$ The trend movement in the terms of trade (PTOT) picks up any permanent wealth effect over time and is estimated by the trend series obtained from a standard Hodrick-Prescott (HP) filter. Following Agenor and Aizenman (2004), the measure is weighted by the ratio of real exports to real GDP in order to capture the fact that the higher the share of exports in output, the higher is the impact of volatility in the terms of trade. The transitory component of the terms of trade (TTOT) measures the temporary shocks and is the filtered series obtained from the use of the HP filter. ${ }^{13}$ This variable is also weighted by the ratio of real exports to real GDP and is anticipated to have a positive impact on savings. A time varying measure of the terms of trade volatility (VTOT) is included as a proxy for income uncertainty. ${ }^{14}$ This should have a negative impact on savings.

The presence of an asymmetric effect of terms of trade on saving is captured by a dummy variable (DUMMY). As suggested in Agenor and Aizenman (2004), the variable used is an interactive dummy, which takes the value of unity times the logarithm of the permanent component of the terms of trade, weighted by the ratio of exports to GDP, when that component increases above its previous value, and zero otherwise.

In addition to the basic set of regressors included in Eq. (1), estimations are also performed using several alternative determinants of savings. Specifically, three variables are selected. Income uncertainty (VINC) is represented by the moving sample standard deviation of the growth rate of per capita real income. This variable is expected to have a positive impact on the savings rate.

Two price variables representing the financial market are also used. First, the real interest rate (RINT) is measured as the difference between 1-year time deposit rate and the expected rate of inflation. ${ }^{15}$

Second, following the structure-conduct-performance analysis, we use the four-bank concentration ratio as an estimator of banking efficiency. ${ }^{16}$

\section{Estimation results}

\subsection{Baseline regression results}

Estimations have been performed using annual unbalanced panel data for 45 countries in Asia, Africa and Latin America for the 1990-2008 sample period. ${ }^{17}$ Annual data was gathered for 61 countries, but 
missing values for several variables reduce the number of countries in the estimation to 45 . The main data source was the International Monetary Fund's International Financial Statistics (IFS-IMF). Remaining data were taken from Penn World Tables, Mark 7.0 (PWT).

Table 1 reports the results of the regression equations for private savings using alternative estimators on the full sample and the basic specification. In order to facilitate comparison with the GMM dynamic panel technique, estimates using cross-section data (column 1) and pooled annual data in static specification without the lagged savings rate (column 2) are presented. Neither of these two specifications takes into account the issues of endogeneity and unobserved country-specific effects. In both cases, the rejection of the null hypothesis for both the error serial correlation tests indicates that the estimated coefficient in these specifications cannot offer valid conclusions as relevant variables with high over-time persistence are not included.

The third regression shown in column 3 is the basic dynamic specification which includes the lagged savings term. Note that consistent with our previous discussion, the panel estimates, by construction, exhibit first-order serial correlation. However, our primary concern is the presence of second-order serial correlation. Both the hypotheses of lack of second-order residual serial correlation and of no correlation between the error term and the instruments (Sargan test) cannot be rejected, indicating support for the dynamic specification as well as for the instruments used in the estimation process. Results from the Wald test of joint significance show that the coefficients are jointly significant.

The coefficient on the lagged private savings rate is, as expected, positive. The value of 0.410 shows the presence of a large degree of persistence. In fact, the view that past savings is an important predictor of current savings in the developing economies appears to be confirmed. This also implies that, if all changes in any of the explanatory variables are permanent, its long-run effect is exactly 1.7 times the short-run effect. ${ }^{18}$ The positive and statistically significant coefficient on the per capita income variable implies that countries with higher per capita income tend to save relatively more than countries with lower per capita income. This confirms the theoretical relationship as shown in an intertemporal model, such as, the life-cycle hypothesis. The business cycle effect, measured by the coefficient on the GDP growth rate, holding the per capita income constant, is statistically insignificant.

The financial depth variable (measured by the ratio of $M 2$ to GDP) has a highly significant negative impact on private savings. When the volume of $\mathrm{M} 2$ rises by 1 percent of GDP, the private savings rate decreases by 0.65 percentage point. This result confirms the widely held view that financial reform may stimulate consumption by relaxing domestic liquidity constraints through, say, increased access to bank credit, and thus reduce the propensity to save. ${ }^{19}$ Similar results have been reported for Sub-Saharan Africa (Agenor and Aizenman, 2004), and 69 developed and developing countries (Loayza et al., 2000). ${ }^{20}$ Inflation has a positive impact on savings. An increase in inflation by 10 percentage points raises private savings by about a quarter of 1 percentage point. This is contrary to the results in Denizer and Wolf (1998) for the transition economies. One explanation could be that, as it represents macroeconomic uncertainty, increased uncertainty about the aggregate economy and expectation of further price increases induces agents to lower their current consumption and increase precautionary savings.

The coefficient on public savings is negative and statistically significant suggesting that the private sector internalizes the government's budget constraint. The short-term coefficient is 0.285 giving a permanent long-term value of 1.4. Since the coefficient is statistically greater than one, we cannot reject Ricardian equivalence for the full sample. 
The dependency ratio variable has the expected negative sign but is marginally significant in the equation. IMF (2000) reported a positive impact of dependency rate on domestic savings in Poland, while Denizer and Wolf (1998) found the impact to be generally negative but insignificant in a group of 25 transition countries during the early years of transition. The lack of a strong negative effect in our sample countries may suggest that substantial changes in the education, social welfare and pension systems have led to an expectation of decline in these benefits, and consequently economic agents are responding by not lowering their own provision for education and retirement. ${ }^{21}$

Table 1. Private savings and terms of trade: Alternative estimators.

\begin{tabular}{|c|c|c|c|}
\hline Estimator & (1) & (2) & (3) \\
\hline Regression & OLS-CS & OLS-static & GMM-systems \\
\hline \multirow[t]{2}{*}{ Instruments } & Levels & Levels & Levels-differences \\
\hline & & & Difference-levels \\
\hline \multirow[t]{2}{*}{$P S(-1)$} & - & - & $0.410^{*}$ \\
\hline & & & $(4.60)$ \\
\hline \multirow[t]{2}{*}{ RPCY } & $0.361^{*}$ & $0.299 *$ & $0.85^{*}$ \\
\hline & $(2.11)$ & $(2.86)$ & (3.14) \\
\hline \multirow[t]{2}{*}{ GRPCY } & 0.085 & 0.093 & 0.115 \\
\hline & $(1.40)$ & $(1.16)$ & $(0.98)$ \\
\hline \multirow[t]{2}{*}{$\mathrm{M} 2 / \mathrm{GDP}$} & -0.259 & $-0.165^{*}$ & $-0.646^{*}$ \\
\hline & (1.98) & $(2.18)$ & (4.13) \\
\hline \multirow[t]{2}{*}{ INF } & $-0.218^{*}$ & $-0.346 *$ & $0.245^{*}$ \\
\hline & $(2.15)$ & (3.11) & (3.18) \\
\hline \multirow[t]{2}{*}{ PUBSAV } & $-0.326^{*}$ & $-0.744 *$ & $-0.285^{*}$ \\
\hline & $(4.14)$ & $(4.80)$ & (5.15) \\
\hline \multirow[t]{2}{*}{ DEP } & -0.066 & -0.112 & $-0.545^{*}$ \\
\hline & (0.99) & $(1.32)$ & $(1.98)$ \\
\hline \multirow[t]{2}{*}{ PTOT } & 0.180 & 0.211 & $0.135^{*}$ \\
\hline & (1.75) & $(1.18)$ & $(3.04)$ \\
\hline \multirow[t]{2}{*}{ ТTOT } & 0.085 & $0.077^{*}$ & $0.293^{*}$ \\
\hline & $(1.96)$ & $(2.16)$ & $(4.14)$ \\
\hline \multirow[t]{2}{*}{ VTOT } & $0.058^{*}$ & $0.094 *$ & $-0.510^{*}$ \\
\hline & $(3.40)$ & $(2.11)$ & $(4.64)$ \\
\hline \multirow[t]{2}{*}{ DUMMY } & 0.003 & 0.002 & $0.038^{*}$ \\
\hline & $(1.46)$ & $(1.02)$ & $(2.34)$ \\
\hline Years indicator & & & Yes \\
\hline Country fixed effect & & & Yes \\
\hline No of observations & & & 720 \\
\hline S.E.E. & 0.173 & 0.184 & 0.109 \\
\hline Wald test & 0.000 & 0.000 & 0.000 \\
\hline Sargan test & - & - & 0.190 \\
\hline Difference Sargan tes & & & 0.180 \\
\hline \multicolumn{4}{|l|}{ Serial correlation test } \\
\hline 1st Order & 0.001 & 0.033 & 0.025 \\
\hline
\end{tabular}




\begin{tabular}{|c|c|c|c|}
\hline Estimator & (1) & (2) & (3) \\
\hline Regression & OLS-CS & OLS-static & c GMM-systems \\
\hline Instruments & Levels & Levels & Levels-differences \\
\hline & & & Difference-levels \\
\hline 2nd Order & 0.003 & 0.048 & 0.210 \\
\hline
\end{tabular}

Note: figures in parentheses are the absolute values of the t-statistics which are computed with heteroscedasticity-consistent standard errors. The $p$-values for the Wald test, Sargan test, Difference Sargan test and first and second-order serial correlation are given.

*Significant at least at the 5 percent level.

Next, consider the variables of interest for this study. Both the permanent and temporary components of the terms of trade are positive and statistically significant. This is similar to the results reported for a group of developing countries in Masson et al. (1998) and both developed and developing countries in Loayza et al. (2000). Moreover, the magnitude of the coefficient on the temporary component is much larger than that of the permanent component. ${ }^{22}$ This reflects the lack of access to foreign borrowing that many of the developing economies have faced during the last two decades. The short-term coefficient on the transitory variable is 0.293 , so the long-term effect is around less than 0.6 . As both these values are significantly less than one, there is an incomplete pass-through in the system. This may be due to the inability of the households to realize fully the degree of persistence of terms of trade shock at the moment they occur. Agenor and Aizenman (2004) report similar findings for Africa.

The volatility of the terms of trade has a statistically significant negative impact on savings. This is contrary to the findings as reported in Agenor and Aizenman (2003). The dummy variable has the anticipated positive sign but is small in magnitude. This suggests that although there is evidence of an asymmetric impact of terms of trade shocks, the size of the impact is relatively small in the transition economies.

\subsection{Alternative determinants}

In this subsection, the basic savings equation (1) is extended by including an augmented set of explanatory variables. The obvious candidates to form part of this group are those that are explicitly implied by economic theory and have been used in empirical studies. The potential determinants are each added separately to the basic equation given in Table 1 (Eq. (1)). The results are reported in Table 2. 
Table 2. Private savings and terms of trade: Alternative determinants.

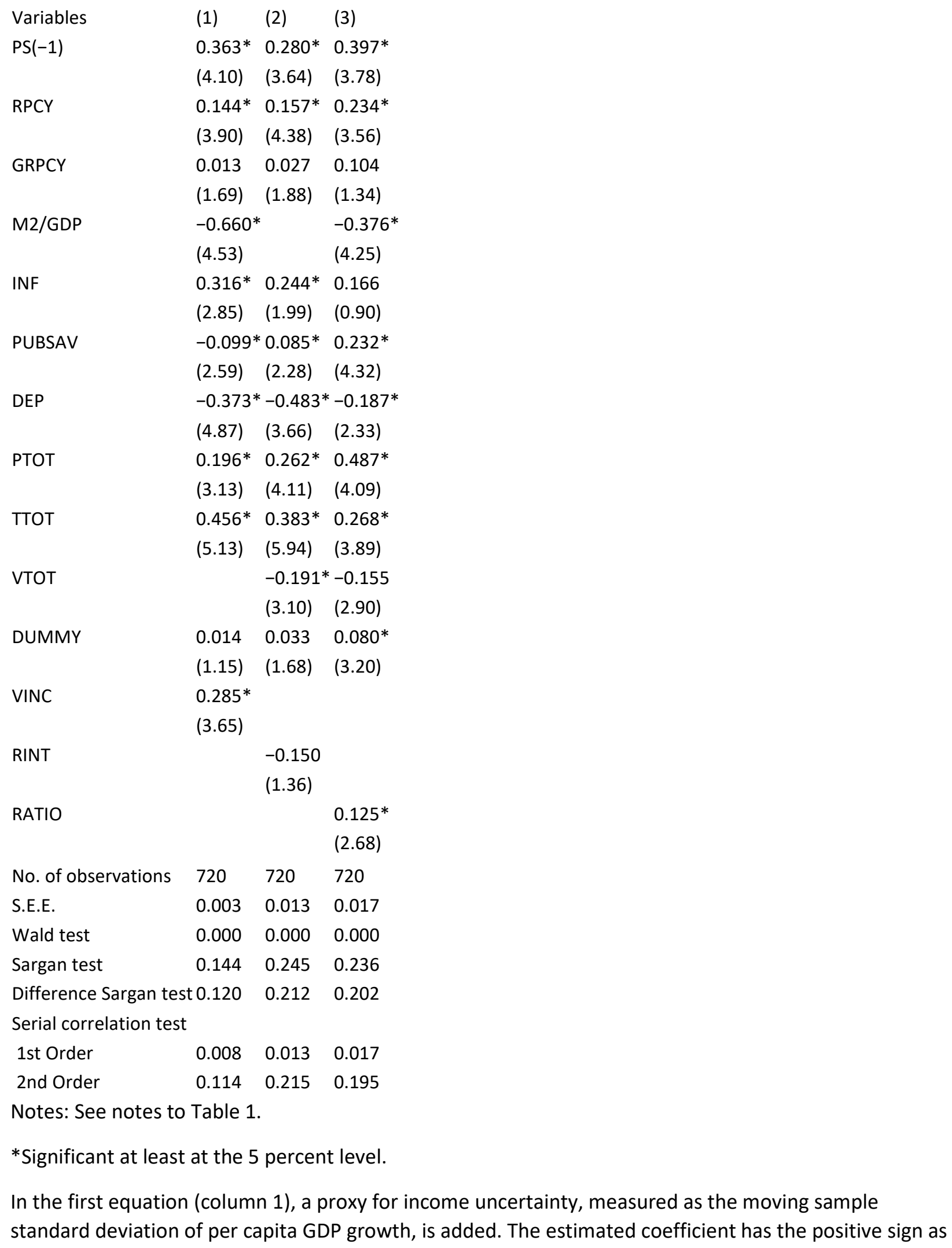


is expected from the precautionary saving motive and is significant. This provides evidence that in response to an increase in the volatility of income, due to, say, an increase in the probability of being unemployed, an economic agent will increase private savings in order to hedge against the greater probability of a large negative income shock in the future. In the presence of the income volatility variable, the inflation variable loses some of its significance indicating that the income variable is capturing some of the inflationary effects of macro-uncertainty.

The next variable added to the basic equation is the real interest rate (column 2). The coefficient is negative but statistically insignificant. ${ }^{23}$ This means that the positive substitution effect of an increase in real interest rate is cancelled out by the negative income effect. Further analysis showed that the real interest rate variable is highly correlated with the inflation rate with a correlation coefficient of 0.71 . This implies that during the sample period considered, the nominal rates adjusted rather slowly to changes in economic fundamentals and that, on average, changes in inflation were dominating the movements in the real interest rates. ${ }^{24}$

The third variable, Concentration ratio (RATIO), is a proxy for banking efficiency in these countries. The coefficient has a positive sign and is statistically significant. Financial reform has improved banking efficiency. This, in turn, has raised conspicuous consumption, thereby lowering private savings. The value of the lagged savings rate varies between 0.280 and 0.397 in the three equations. The degree of persistence remains strong in the presence of additional regressors. The values for the other explanatory variables in the table are qualitatively similar to those found in the basic regression equation given in Table 1.

\subsection{Sensitivity analysis}

As the developing countries have experienced wide variation in their growth process, the robustness of the results to regional coverage is investigated. First, the basic model is re-estimated while removing one country at a time. The process ensures that any undue effects of an outlier country will be reflected by significantly different results for the sample omitting that county. Although the coefficient estimates (not reported here) varied slightly, there is no qualitative change in the results.

Next, it is investigated if the relationship between various significant measures of terms of trade shocks and the savings rate is robust or fragile to small changes in the conditioning information set. The reliability and robustness of the relationship are evaluated using a version of Leamer's (1983) extreme bounds analysis as developed in Levine and Renelt (1992). ${ }^{25}$ In particular, the following regression is estimated:

(2)

$\mathrm{PS}=a+b_{i} \boldsymbol{I}+c_{z} \boldsymbol{Z}+u$

where PS is the savings rate, $I$ is the set of base variables of interest included in all regressions and $Z$ is a subset of variables selected from a pool of potentially important explanatory variables of savings. We first run a base regression that includes only the I variables. Then we compute the regression results for all possible linear combinations of up to three $Z$ variables and identify the lowest and highest values for the coefficients in the I vectors of variables that cannot be rejected at the 5 percent level of significance. If the estimated coefficients remain significant over this procedure, the correlation is said to be 'robust'. The 'extreme bounds' are the highest estimated correlation plus two standard errors and the lowest 
minus two standard errors. If the coefficient fails to be significant in some regression, the correlation is termed 'fragile'.

Four variables earlier found to be statistically significant are included in the I vector - TTOT, PTOT, VTOT and PS(-1). The pool from which the set of three control variables $Z$ is drawn includes all the remaining nine explanatory variables used in Tables 1 and 2. During estimation, we select three variables from the pool of nine variables each time, add these three variables to the base regression of four variables, and see whether the parameters in the base regression are stable or not. The extreme bound results are given in Table 3.

Table 3. Extreme bound analysis.

\begin{tabular}{|c|c|c|c|c|}
\hline \multicolumn{3}{|c|}{ Variable Bound Bi } & \multicolumn{2}{|c|}{ Sargan test 1 st Order serial correlation 2 nd Order serial corr. } \\
\hline & High & $1.45(3.60) 0.33$ & 0.02 & 0.18 \\
\hline \multirow[t]{3}{*}{$P S(-1)$} & Base & $1.22(3.05) 0.35$ & 0.02 & 0.19 \\
\hline & Low & $0.98(3.00) 0.38$ & 0.05 & 0.22 \\
\hline & High & $0.36(2.80) 0.15$ & 0.00 & 0.15 \\
\hline \multirow[t]{3}{*}{ PTOT } & Base & $0.30(2.15) 0.10$ & 0.00 & 0.18 \\
\hline & Low & $0.18(2.70) 0.08$ & 0.01 & 0.22 \\
\hline & High & $0.86(3.18) 0.22$ & 0.04 & 0.37 \\
\hline \multirow[t]{3}{*}{ ТтОТ } & Base & $0.45(3.08) 0.28$ & 0.06 & 0.41 \\
\hline & Low & $0.22(2.76) 0.31$ & 0.07 & 0.53 \\
\hline & High & $1.77(2.15) 0.44$ & 0.03 & 0.60 \\
\hline \multirow[t]{2}{*}{ VTOT } & Base & 1.03 (2.05) 0.40 & 0.05 & 0,50 \\
\hline & Low & $0.85(2.78) 0.28$ & 0.03 & 0.53 \\
\hline
\end{tabular}

Note: the base ' $B$ ' is the estimated coefficient of the I variable in Eq. (2) when private savings rate is regressed, using $2 S L S$, on the I and $Z$ variables. The high ' $\mathrm{B}$ ' is the estimated coefficient from the regression with the extreme high bound ( $\mathrm{Bi}+$ two standard deviations); the low ' $\mathrm{B}$ ' is the coefficient from the regression with the extreme lower bound. Only the absolute values of ' $B$ ' coefficient are reported. The figures in parentheses are absolute values of the t-statistics which are computed with heteroscedasticity-consistent standard errors. All the reported coefficients are significant at least at the 5 percent level.

The GMM system estimator results appear to be robust. The four key variables keep the right sign, remain significant, and have values for the estimated coefficient that are consistent with those reported in the paper. For PS(-1), PTOT, TTOT and VTOT, the ranges are $(0.98,1.45),(0.18,0.36),(0.22,0.86)$ and $(0.85,1.77)$, respectively. In summary, the coefficient estimates are fairly stable and insensitive to various extra regressors.

\subsection{Country groupings}

Given the differences in institutional characteristics and macro-performance across different countries in different regions, we then re-estimate the model separately for three groups - the countries in Asia, Africa, and Latin America. ${ }^{26}$ These results are given in Table 4. 
Table 4. Private savings and terms of trade shocks: Alternative country groupings.

\begin{tabular}{|c|c|c|c|c|}
\hline \multicolumn{5}{|l|}{ Regions } \\
\hline Variables & All & Asia & Africa & Latin America \\
\hline \multirow[t]{2}{*}{$P S(-1)$} & $0.410^{*}$ & $0.388^{*}$ & $0.514^{*}$ & $0.647^{*}$ \\
\hline & $(4.60)$ & (3.15) & (4.57) & $(5.10)$ \\
\hline \multirow[t]{2}{*}{ RPCY } & $0.850^{*}$ & $0.531 *$ & $0.112 *$ & $0.212^{*}$ \\
\hline & $(3.14)$ & $(3.77)$ & (3.10) & $(3.25)$ \\
\hline \multirow[t]{2}{*}{ GRPCY } & 0.115 & -0.210 & -0.188 & 0.251 \\
\hline & (0.98) & $(1.41)$ & $(1.76)$ & $(0.65)$ \\
\hline \multirow[t]{2}{*}{$\mathrm{M} 2 / \mathrm{GDP}$} & $-0.646^{*}$ & $-0.514 *$ & $-0.298 *$ & $-0.234^{*}$ \\
\hline & (4.13) & (3.66) & (3.54) & $(2.12)$ \\
\hline \multirow[t]{2}{*}{ INF } & $0.245^{*}$ & $0.266^{*}$ & $0.187^{*}$ & $0.198 *$ \\
\hline & $(3.18)$ & $(3.88)$ & $(2.90)$ & $(3.17)$ \\
\hline \multirow[t]{2}{*}{ PUBSAV } & $-0.285^{*}$ & $-0.233^{*}$ & $-0.225^{*}$ & $-0.130 *$ \\
\hline & $(5.15)$ & $(4.33)$ & $(5.34)$ & $(3.40)$ \\
\hline \multirow[t]{2}{*}{ DEP } & $-0.545^{*}$ & -0.222 & -0.298 & $-0.378 *$ \\
\hline & (1.98) & (1.69) & $(1.75)$ & $(2.48)$ \\
\hline \multirow[t]{2}{*}{ PTOT } & $0.135^{*}$ & $0.188^{*}$ & $0.056^{*}$ & $0.085^{*}$ \\
\hline & (3.04) & $(2.68)$ & $(2.94)$ & $(2.80)$ \\
\hline \multirow[t]{2}{*}{ TTOT } & $0.293^{*}$ & $0.433^{*}$ & $0.112^{*}$ & $0.188^{*}$ \\
\hline & $(4.14)$ & $(5.10)$ & $(2.77)$ & (3.18) \\
\hline \multirow[t]{2}{*}{ VTOT } & $-0.510^{*}$ & $-6.43^{*}$ & $-0.353^{*}$ & $-0.544^{*}$ \\
\hline & $(4.64)$ & $(5.38)$ & (3.76) & $(4.32)$ \\
\hline \multirow[t]{2}{*}{ DUMMY } & $0.038^{*}$ & $0.088 *$ & $0.064^{*}$ & $0.052 *$ \\
\hline & $(2.34)$ & (3.16) & $(2.77)$ & $(2.70)$ \\
\hline No. of observations & 720 & 208 & 256 & 256 \\
\hline S.E.E. & 0.109 & 0.210 & 0.123 & 0.142 \\
\hline Wald test & 0.000 & 0.000 & 0.000 & 0.000 \\
\hline Sargan test & 0.190 & 0.244 & 0.218 & 0.320 \\
\hline Difference Sargan test & 0.172 & 0.220 & 0.190 & 0.286 \\
\hline \multicolumn{5}{|l|}{ Serial correlation } \\
\hline 1st Order & 0.025 & 0.011 & 0.031 & 0.048 \\
\hline 2nd Order & 0.210 & 0.166 & 0.184 & 0.216 \\
\hline
\end{tabular}

Note: See notes to Table 1.

*Significant at least at the 5 percent level.

For purposes of comparison, the results from the basic equation for the entire sample countries are reproduced in column 1 . The coefficient on the lagged private savings is positive and statistically significant in all the three country groups. The value varies from a low of 0.388 in the Asian countries to a high of 0.647 in the Latin American countries, indicating the presence of a large degree of persistence in these countries. Although there is no major difference among the other regression results for the three groups, a number of intriguing nuances in the pattern of savings in the three groups are evident. The coefficient on public savings is negative and statistically significant in all three groups, showing that 
the private sector in these countries internalizes the government budget constraints. However, the short-run magnitude of this effect are $-0.233,-0.225$ and -0.133 in the three groups, respectively. This is far below the one-to-one relationship suggested by the simple Ricardian equivalence doctrine. The absolute values of the coefficients of the per capita income (RPCY) and monetization variables are much higher in the Asian countries than in the other two groups, indicating that private savings in the Asian countries are more sensitive to changes in these two variables. The monetization variable has important policy implications in terms of prioritizing financial reforms in these countries. Countries with a relatively more developed financial system tend to generate a lower level of private savings. In other words, the availability of more credit instruments tends to raise the consumption level of the consumers. This finding supports the UN (2001) view that any further catching up in these variables (considering the fact that average per capita income level and monetization in the Asian countries are higher those in the other two groups) might be expected to produce a slower rate of catching up in private savings.

The behavior of the variables of interest - permanent and temporary components of terms of trade shocks, its variability and the dummy variable measuring asymmetric shocks - shows some differences. All the variables are positive and statistically significant. However, the magnitude of each of the variables is smaller in African countries than in the other two country groupings. This seems to be counterintuitive. Given that the trade in African countries is more dependent on primary commodities, terms of trade shocks should have a larger impact on private savings in these countries.

\section{Conclusion}

Using data from 45 developing countries, this paper analyzes the impact of terms of trade shocks on private savings after accounting for other determinants. Given the absence of efficient domestic credit and capital markets and limited access to international financial markets, economic agents in the developing economies are subject to tight credit constraints which are more pronounced during bad state of nature. Thus, adverse shocks to commodity prices in world market force them to reduce savings by a larger amount than they would otherwise have. The opposite happens during the good times. As the households internalize the likelihood of facing binding borrowing constraints during bad times, they may also lower consumption and save more during good times.

A number of more specific conclusions can also be derived. First, private savings rate is highly persistent in these economies. The effect of a change in one of the determinants of savings is fully realized only after a number of years. Long-term responses are approximately two times that of the short-term responses.

Second, private savings rate rises with the level of real per capita income. So policies that stimulate development can indirectly raise savings rate. Third, financial reform has adversely affected private savings in these countries. Larger financial depth, higher real interest rates and interest rate margin changes fail to increase the private savings rate. The adverse effect is more pronounced in the African countries than in the Asian and Latin American countries. Reform in the financial sector has stimulated consumption by relaxing domestic liquidity constraints through, say, increased access to bank credit, and thus reduced the propensity to save.

Fourth, macroeconomic instability, measured by inflation rate, causes an increase in the precautionary motive to save. Similar behavior is evident when volatility of income is introduced in the model. The advent of high inflation and high unemployment, along with cuts in public benefits have raised income 
uncertainty and changed expected future income profiles in these countries. ${ }^{27}$ The results in this paper show that households have responded by increasing precautionary savings.

Fifth, the private sector internalizes the government's budget constraint. The Ricardian equivalence is rejected for all three country groupings. Sixth, a marginally negative impact of an increase in the dependency rate on private savings is evident suggesting that a smoothing out of uneven income flows over the life cycle may not be the main motive for saving.

Finally, in contrast to the intertemporal choice literature, this paper finds the permanent component of the terms of trade to have a significant positive impact on private savings. Transitory movements in the terms of trade also have a significant positive impact and a larger magnitude than the permanent component. This reflects the lack of access to foreign borrowing that many of the developing economies have faced during the last decade. Although the impact of terms of trade shocks is found to be asymmetric in the developing economies, the magnitude of the impact appears to be relatively small.

\section{Appendix A}

List of 45 countries in the sample.

$\begin{array}{lll}\text { Asia (13) } & \text { Africa (16) } & \text { Latin America (16) } \\ \text { Bangladesh Benin } & \text { Argentina } \\ \text { Cambodia } & \text { Botswana } & \text { Belize } \\ \text { India } & \text { Cameroon } & \text { Bolivia } \\ \text { Indonesia } & \text { Chad } & \text { Brazil } \\ \text { Korea } & \text { Ghana } & \text { Chile } \\ \text { Malaysia } & \text { Kenya } & \text { Colombia } \\ \text { Nepal } & \text { Malawi } & \text { Ecuador } \\ \text { Pakistan } & \text { Mali } & \text { Guatemala } \\ \text { Philippines } & \text { Mauritius } & \text { Honduras } \\ \text { Singapore } & \text { Mozambique Mexico } \\ \text { Sri Lanka } & \text { Niger } & \text { Nicaragua } \\ \text { Thailand } & \text { Senegal } & \text { Panama } \\ \text { Vietnam } & \text { South Africa } & \text { Paraguay } \\ & \text { Tanzania } & \text { Peru } \\ & \text { Uganda } & \text { Uruguay } \\ & \text { Zambia } & \text { Venezuela }\end{array}$

\section{References}

Adler and Magud, 2013, Adler, Gustavo, Magud, Nicholas, 2013. Four Decades of Terms of Trade Booms: Saving-Investment Patterns and a New Metric of Income Windfall. IMF Working Paper WP/13/103.

Agenor and Aizenman, 2004. Pierre Agenor, Joshua Aizenman. Savings and the terms of trade under borrowing constraints. Journal of International Economics (June) (2004), pp. 321-340

Alessie and Lusardi, 1997. Rob Alessie, Annamaria Lusardi. Consumption, saving and habit formation. Economics Letters, 55 (1997), pp. 103-108 
Aquino and Espino, 2013. Aquino, Juan, Espino, Freddy, 2013. Terms of Trade and Current Account Fluctuations: A Vector Autoregression Approach. Working Paper Series, Central Reserve Bank of Peru, June.

Arellano and Bond, 1991. Manuel Arellano, Stephen Bond. Some tests of specification for panel data: Monte Carlo evidence and an application to employment equations. Review of Economic Studies, 58 (1991), pp. 277-297

Arellano and Bover, 1995. Manuel Arellano, Olympia Bover. Another look at the instrumental variable estimation of error-component models. Journal of Econometrics, 68 (1995), pp. 29-51

Attanasio and Weber, 2010. Orazio Attanasio, Guglielmo Weber. Consumption and saving: models of intertemporal allocation and their implications for public policy. Journal of Economic Literature, 48 (September) (2010), pp. 693-751

Baxter and Kouparitsas, 2000. Baxter, Marianne, Kouparitsas, Michael, 2000. What can Account for Fluctuations in the Terms of Trade? National Bureau of Economic Research Working Paper No. 10725.

Bevan et al., 1993. David Bevan, Paul Collier, Jan Gunning. Trade shocks in developing countries: consequences and policy responses. European Economic Review, 37 (1993), pp. 557-565

Blanchard and Fischer, 1989. Oliver Blanchard, Stanley Fischer. Lectures on Macroeconomics, MIT Press, Cambridge, MA (1989)

Blundell and Bond, 1998. Richard Blundell, Stephen Bond. Initial conditions and moment restrictions in dynamic panel data models. Journal of Econometrics, 87 (1998), pp. 115-143

Bosworth, 1993. Barry Bosworth. Savings and Investment in an Open Economy. Brookings Institution, Washington, DC (1993)

Campos and Coricelli, 2002. Nauro Campos, Frank Coricelli. Growth in transition: what we know, what we don't, and what we should. Journal of Economic Literature, XL (3) (2002), pp. 793-836

Campos and Kinoshita, 2002. Nauro Campos, Yuko Kinoshita. Foreign direct investment as technology transferred: some panel evidence from the transition economies. The Manchester School, 70 (2002), pp. 398-419

Cardenas et al., 2011. Mauricio Cardenas, Santiago Ramirez, Didem Tuzemen. Commodity Dpendence and Fiscal Capacity, Brookings Institution, Latin American Initiative (2011). April 1

Cashin and McDermott, 2002. Paul Cashin, John McDermott. Terms of trade shocks and the current account: evidence from five industrial countries. Open Economies Review, 13 (2002), pp. 219235

Cashin et al., 2002. Paul Cashin, John McDermott, Alasdair Scott. Booms and slumps in world commodity prices. Journal of Development Economics, 69 (2002), pp. 277-296

Cespedes and Velasco, 2011. Cespedes, Luis, Velasco, Andres, 2011. Was This Time Different? Fiscal Policy in Commodity Republics. BIS Working Papers 365 (Basle: Bank of International Settlements).

Chowdhury, 1993. Abdur Chowdhury. Does exchange rate volatility depress trade flows? Evidence from error-correction models. The Review of Economics and Statistics, 75 (1993), pp. 700-706

Chowdhury, 2001a. Chowdhury, Abdur, 2001a. The Impact of Financial Reform on Private Savings in Bangladesh. World Institute for Development Economics Research, Discussion Paper No. 2001/78, Helsinki.

Chowdhury, 2001b. Chowdhury, Abdur, 2001b. External Debt and Growth in Developing Countries. World Institute for Development Economics Research, Discussion Paper No. 2001/95, Helsinki.

Chowdhury, 2004. Abdur Chowdhury. Private savings in transition economies: are there terms of trade shocks? Comparative Economic Studies, 46 (2004), pp. 487-514

Collins, 1991. Susan Collins. Saving behavior in ten developing countries. D. Bernheim, J. Shoven (Eds.), National Saving and Economic Performance, University of Chicago Press, Chicago (1991) 
Corden, 1984. Corden, Warner, 1984. Booming sector and Dutch disease economics: survey and consolidation. Oxford Economic Papers 36, 359-380.

Dabla-Norris and Srivisal, 2013. Dabla-Norris, Era, Srivisal, Narapong, 2013. Revisiting the Link between Finance and Macroeconomic Volatility. IMF Working Paper Series WP/13/29.

Dayal-Gulati and Thimann, 1997. Dayal-Gulati, Anuradha, Thimann, Christian, 1997. Saving in Southeast Asian and Latin America Compared: Searching for Policy Lessons. IMF Working Paper WP/97/110.

Deaton and Laroque, 1992. Angus Deaton, Guy Laroque. On the behavior of commodity prices. Review of Economic Studies, 59 (1992), pp. 1-23

Denizer and Wolf, 1998. Denizer, Cevdet, Wolf, Holger, 1998. Aggregate Savings in the Transition. Saving Across the World Project, The World Bank, Washington, DC, December.

Dornbusch, 1983. Rudiger Dornbusch. Real interest rates, home goods, and optimal external borrowing. Journal of Political Economy, 91 (1983), pp. 141-153

Edison et al., 2002. Hali Edison, Ross Levine, Luca Ricci, Torsten Slok. International financial integration and economic growth. Journal of International Money and Finance, 21 (2002), pp. 749-776

Edwards, 1989. Sebastian Edwards. Temporary terms of trade disturbances, the real exchange rate and the current account. Economica, 56 (1989), pp. 343-357

Fischer, 1993. Stanley Fischer. The role of macroeconomic factors in growth. Journal of Monetary Economics, 32 (1993), pp. 485-512

Harberger, 1950. Arnold Harberger. Currency depreciation, income and the balance of trade. Journal of Political Economy, 53 (1950), pp. 47-60

International Monetary Fund, 2000. International Monetary Fund, 2000. World Economic Outlook: Focus on Transition Economies. October, Washington, DC.

Jappelli and Pagano, 1995. Tullio Jappelli, Marco Pagano. Savings, growth, and liquidity constraints. Quarterly Journal of Economics, 109 (1995), pp. 83-109

Kent, 1997. Kent, Christopher, 1997. The Response of the Current Account to Terms of Trade Shocks: A Panel Data Study. Reserve Bank of Australia, Research Discussion Paper 9705.

Kent and Cashin, 2003. Kent, Christopher, Cashin, Paul, 2003. The Response of the Current Account to Terms of Trade Shocks: Persistence Matters. International Monetary Fund Working Paper WP/03/143.

King and Rebelo, 1993. Robert King, Sergio Rebelo. Low frequency filtering and real business cycles. Journal of Economic Dynamics and Control, 17 (1993), pp. 207-231

Koivu, 2002. Koivu, Tuli, 2002. Does Financial Sector Development Affect Economic Growth in Transition Economies? Mimeo, Institute for Transition Economies, Bank of Finland, Helsinki.

Kraay, 2000. Aart Kraay. Household saving in China. World Bank Economic Review, 14 (3) (2000), pp. 545-570

Lahiri, 1989. Lahiri, Ashok, 1989. Dynamics of Asian savings: the role of growth and age structure. IMF Staff Papers 36, 228-261.

Laursen and Metzler, 1950. Stephen Laursen, Lloyd Metzler. Flexible exchange rates and the theory of employment. Review of Economics and Statistics, 32 (1950), pp. 281-299

Leamer, 1983. Edward Leamer. Let's take the con out of econometrics. American Economic Review, 73 (1983), pp. 31-43

Levine and Renelt, 1992. Ross Levine, David Renelt. A sensitivity analysis of cross country growth regressions. American Economic Review, 82 (1992), pp. 942-963

Loayza et al., 2000. Norman Loayza, Klaus Schmidt-Hebbel, Luis Serven. What drives private saving across the world? The Review of Economics and Statistics, 82 (2) (2000), pp. 165-181

Masson et al., 1998. Paul Masson, Tamim Bayoumi, Hossein Samiei. International evidence on the determinants of private savings. The World Bank Economic Review, 12 (1998), pp. 483-501 
Obstfeld, 1982. Maurice Obstfeld. Aggregate spending and the terms of trade: is there a LaursenMetlzer Effect? Quarterly Journal of Economics, 47 (1982), pp. 251-270

Ogaki et al., 1996. Ogaki, Masao, Ostry, Jonathan, Reinhart, Carmen, 1996. Saving behavior in low- and middle-income developing countries: a comparison. IMF Staff Papers 43, 38-71.

Osterholm and Zettelmeyer, 2008. Par Osterholm, Jeromin Zettelmeyer. The effect of external conditions on growth in Latin America. IMF Staff Papers, 55 (4) (2008), pp. 595-623

Ostry and Reinhart, 1992. Ostry, Jonathan, Reinhart, Carmen, 1992. Private saving and terms of trade shocks. IMF Staff Papers 39, 495-517.

Otto, 2003. Geoffrey Otto. Terms of trade shocks and the balance of trade: there is a HarbergerLaursen-Metzler effect. Journal of International Money and Finance, 22 (2003), pp. 155-184

Radulescu and Barlow, 2002. Roxana Radulescu, David Barlow. The relationship between policies and growth in transition countries. Economics of Transition, 10 (3) (2002), pp. 719-746

Reinhart and Wickham, 1994. Reinhart, Carmen, Wickham, Peter, 1994. Commodity prices: cyclical weakness or secular decline? IMF Staff Papers 41, 175-213.

Sachs, 1981. Sachs, Jeffrey, 1981. The current account and macroeconomic adjustments in the 1970s. Brookings Papers on Economic Activity 1, 201-268.

Spatafora and Warner, 1999. Spatafora, Nikola, Warner, Andrew, 1999. Macroeconomic and Sectoral Effects of Terms of Trade Shocks: The Experience of the Oil-exporting Developing Countries. IMF Working Paper WP/99/134, October.

Svensson and Razin, 1983. Lars Svensson, Assaf Razin. The terms of trade and current account: the Harberger-Laursen-Metlzer effect. Journal of Political Economy, 91 (1983), pp. 97-125

United Nations, 2001. United Nations, 2001. Economic Survey of Europe. Prepared by the Secretariat of the Economic Commission for Europe, Geneva.

United Nations, 2002. United Nations, 2002. Economic Survey of Europe. No. 1, Prepared by the Secretariat of the Economic Commission for Europe, Geneva.

Windmeijer, 2004. Frank Windmeijer. A finite sample correction for the variance of linear efficient two step GMM estimators. Journal of Econometrics, 126 (1) (2004), pp. 25-51

World Bank, 2013. World Bank, 2013. World Economic Situation and Prospects. Washington, DC.

Zeldes, 1989. Stephen Zeldes. Consumption and liquidity constraints: an empirical investigation. Journal of Political Economy, 97 (2) (1989), pp. 305-346

${ }^{1}$ For an early work in this area, see Bevan et al. (1993). Attanasio and Weber (2010) provides a detail review of the theoretical and empirical literature on this issue. Adler and Magud (2013) studies the relationship over the last four decades.

${ }^{2}$ Several studies have also emphasized the importance of trade dynamics in the process of transition (see Chowdhury (2004), and Campos and Coricelli (2002) and the references therein).

${ }^{3}$ Reinhart and Wickham (1994) show that commodity prices have experienced a mostly secular decline accompanied by an increase in volatility. The standard deviation for terms of trade growth has ranged from an average of 9 percent per year for developed countries to about 19 percent per year for developing countries (Baxter and Kouparitsas, 2000). The World Bank's index of non-oil real commodity prices has also shown a trend decline of about 1.5 percent per annum since the late 1940s. The Bank predicts this trend to continue over the next decade.

${ }^{4}$ Cashin et al. (2002) found commodity price cycles to be asymmetric - price slumps last longer than price booms. Averaging across 36 real commodity price series, they estimated the typical length of price slumps (39 months) to be about 10 months longer than the typical length of price booms, giving an average cycle of about 68 months. Using a stock-holding model with intertemporal arbitrage, Deaton and Laroque (1992) identified the asymmetry involved in storage activity - stocks cannot be negative and a stock-out will lead to sharp price fluctuations - as the reason for this pattern of commodity price movements. 
${ }^{5}$ For a survey of early works in this area, see Ostry and Reinhart (1992).

${ }^{6}$ Ogaki et al. (1996) have shown that in low-income countries, where levels of income are near the subsistence level, consumption-tilting and real exchange rate effects have a relatively limited impact on savings. Their results provide support to the consumption smoothing view of HLM that transitory adverse disturbances in the terms of trade in these countries tend to lower private savings.

${ }^{7}$ This dynamic specification helps to differentiate between short- and long-run effects on savings (see Loayza et al., 2000).

${ }^{8}$ For an excellent summary of various determinants of savings and findings from previous empirical studies, see Chowdhury (2004) and Loayza et al. (2000).

${ }^{9}$ Alessie and Lusardi (1997) consider models of habit formation and show that savings depend not only on future income changes and income risk, but also on past saving. There is also an econometric reason for including this variable. The error process in a dynamic specification suffers from a potential problem of serial correlation. This has important implication for both the validity test of the instruments used in the estimation process as well as its impact on the consistency of the estimates. In order to specify a dynamic regression with uncorrelated disturbances, lagged value of savings should be included as an additional control.

${ }^{10}$ See, for example, the papers by Blanchard and Fischer (1989) and Bosworth (1993).

${ }^{11}$ Further disaggregation of population by old and young age, to account for unequal income flows over the life cycle, would have been beneficial. But consistent data for all the countries are not available. Following Kraay (2000), estimations are also performed using a slight variation of this variable (ratio of population to employment). The results did not change much.

${ }^{12}$ The terms of trade indices may not be the perfect indicator of a country's exposure to commodity price volatility per se, because they contain various non-commodity price component. But given the data constraint, this was the best possible proxy available. Following Otto (2003), we also used a different measure of terms of trade - the price of exports divided by the price of imports, where the price of export and import are measured by their respective national accounts deflators (for goods and services). The data are taken from the World Bank's World Tables database. However, initial estimations provided results which are qualitatively similar to those given in the paper.

${ }^{13}$ The use of the HP Filter has, however, been criticized on the ground that it removes potentially valuable information from the time series (King and Rebelo, 1993). To alleviate this problem, estimations are also performed using terms of trade ratios. The results are not significantly different from those reported in the paper.

${ }^{14}$ Following the method discussed in Chowdhury (1993), the variable is constructed by the moving sample standard deviation of the growth rate of the terms of trade

$$
V_{t}=\left[(1 / k) \sum\left(A P T A R A N O R M A L \log Q_{t-i-1}-A P T A R A N O R M A L \log Q_{t-i-2}\right)^{2}\right]^{1 / 2}
$$

where $\mathrm{k}=3$ is the order of the moving average. Estimations have also been performed using $k=2$. The conclusion appears to be robust irrespective of the value of $k$.

${ }^{15}$ To overcome the problem of unobservable expected inflation rate, it is assumed that expectations are formed according to the adaptive expectation model, that is, pte $-p t-1 e=b(p t e-p t-1 e)$ where $b$ is the coefficient of expectations such that $0<b<1$.

${ }^{16} \mathrm{~A}$ Referee suggested the use of this variable. As an alternative, the difference between the lending and deposit rates in banking sector is also used as an estimator of banking efficiency. Koivu (2002) has shown that a decrease in this rate differential due to a fall in the transaction costs would lead to a higher share of savings going to investment, thereby accelerating economic growth. The results are qualitatively similar. 
${ }^{17}$ Countries in the sample include thirteen from Asia, and sixteen each from Africa and Latin America, respectively. A complete list of the countries is given in Appendix A. Availability of data constrained the choice of countries, sample period, and variables. To minimize balance problems, countries included in the sample have at least five observations. We started with 855 observations. Since three observations per country were used for constructing the instruments, the basic regression sample consists of 720 observations.

${ }^{18}$ Given the short span of the sample period, distinction between the short- and long-run is not as clearcut as is preferable.

${ }^{19}$ The financial depth variable is also a measure of financial wealth for the private sector in the early years of the transition. It, therefore, follows that savings will rise as accumulated wealth falls in real terms.

${ }^{20}$ Chowdhury (2001a) and Jappelli and Pagano (1995) also report a negative relationship between financial reform and private savings in the developing countries.

${ }^{21}$ Collins (1991) has argued that in order for savings rate to be negatively associated with dependency rates, it requires the assumption that the economy is growing. Following her suggestion, the regression has been re-estimated adding an interaction term of dependency rate and growth. The results are qualitatively similar to those reported in the paper.

${ }^{22}$ When Cashin and McDermott (2002) decomposed terms of trade movements in five OECD countries into their permanent and temporary components, they found the temporary component to be large for all countries, accounting for about half of the variance of the quarter to quarter changes in the terms of trade.

${ }^{23}$ Ogaki et al. (1996) also found private savings to be insensitive to changes in the real interest rates in a number of low- and middle-income developing countries.

${ }^{24}$ In addition to government controls, the rigidity in nominal interest rates has been due to a number of factors, including the oligopolistic nature of the domestic banking system, inadequate banking supervision, and relatively thin domestic money, credit and capital markets.

${ }^{25}$ See Chowdhury (2001b) and the references therein for an application of this procedure. Radulescu and Barlow (2002) employed the extreme bound analysis for a group of transition economies.

${ }^{26} \mathrm{Although}$ the division is arbitrary and the countries within the three groups are not homogenous, it seems to be a natural choice for comparison with other studies.

${ }^{27}$ Anticipated increases in world food prices provoked by droughts in various producer regions, persistently high oil prices and some country specific supply-side constraints continue to put some pressure on inflation in developing countries (World Bank, 2013). 